\title{
A History of the University in Europe, Vol. I Universities in the Middle Ages, ed. Hilde de Ridder-Symoens, Cambridge 1992, ss. 506.
}

W roku 1992 ukazał się pierwszy tom $\mathrm{z}$ opracowywanego przez międzynarodowe grono specjalistów cyklu omawiającego dzieje uniwersytetów europejskich. Tom ten poświęcony jest początkom tych instytucji w czasach średniowiecza. Wydano wersję angielską i niemiecką.

Głównym redaktorem jest Walter Rüegg, tom pierwszy, podobnie jak i zapowiadany drugi, który ma objąć okres 1500 - 1800 redaguje Hilde de Ridder-Symoens. Wśród autorów pochodzących $z$ różnych krajów Europy znajdujemy również przedstawiciela nauki polskiej - Aleksandra Gieysztora.

Całość składa się z czterech części podzielonych w dalszej kolejności na rozdziały, napisanych przez różnych autorów oraz epilogu zapowiadającego zja wisko charakterystyczne dla następnej epoki - humanizm i jego wpływ na dzieje i przemiany uniwersytetów.

We wstępie autorstwa Waltera Rüegga przedstawione zostały podstawowe założenia, przed którymi stanęli autorzy tego tomu oraz całości dziejów uniwersytetów.

Część pierwsza zawiera dwa rozdziały - napisane przez Waltera Rüegga i Jacquesa Vergera. Pierwszy omawia historiografię początków uniwersytetów, oczekiwania jakie miały wobec nich władze kościelne, państwowe i miejskie, ich uczniowie i studenci oraz pochodzenie i zakres fakultetów. Drugi natomiast zajmuje się uniwersytetem jako studium generaie, uniwersytetem jako wspólnotą, narodzinami uniwersytetów i ich zróżnicowaniem. Zawiera również listę uniwersytetów średniowiecznych oraz mapy przedstawiające ich rozmieszczenie - ogólnie oraz z uwzględnieniem poszczególnych etapów ich powstania.

Druga część skladająca się z trzech rozdziałów poświęcona jest strukturom uniwersyteckim. Paolo Nardi zajął się stosunkami uniwersytetów z papiestwem i cesarstwem, począwszy od wieku XII skończywszy na wielkiej schizmie. Aleksander Gieysztor omówił zagadnienia związane $z$ kierowaniem $i$ dochodami uniwersytetów $-\mathrm{z}$ uwzględnieniem podziałów na wydziały, nacje, kolegia oraz zagadnienia budynków i insygniów uniwersyteckich. Opracowana przez Jacquesa Vergera część poświęcona jest nauczycielom uniwersyteckim. Zawiera uwagi na temat tytułów naukowych, karier nauczycielskich, wynagrodzeń nauczycieli, obrazu nauczyciela akademickiego i jego pozycji w średniowiecznym społeczeństwie.

Trzecia część dotyczy problematyki studenckiej. Pierwszy rozdział autorstwa Rainera Ch. Schwingesa poświęcony jest przyjmowaniu na studia. Kolejno omawia dostępność ówczesnych uniwersytetów, immatrykulację, przysięge i oplaty. Następny, napisany przez tego samego autora, dotyczy nauczania i życia studenckiego. Omawia min. pochodzenie społeczne studentów średniowiecznych, związki studenckie, życie codzienne, uczenie się, wreszcie koszty utrzymania. Peter Moraw zajął się natomiast zagadnieniem kariery posiadaczy uniwersyteckich tytułów naukowych w ówczesnej Europie, którą dzieli na „starq" - Wlochy, Francja, część Hiszpanii - i „młodq" - Europa centralna, wschodnia i północna. Tak więc, obok kryterium chronologicznego, wprowadza podział terytorialny $\mathrm{z}$ uwzględnieniem etapów rozwoju historycznego. Ostatni rozdział tej części autorstwa Hildy de Ridder-Symoens poświęcony jest zagadnieniu ruchliwości (mobilności) ludzi średniowiecza, przede wszystkim - rzecz jasna - mobilności studenckiej.

Ostatnia część dotyczy problematyki nauczania. Omówione są kolejno poszczególne wydziały średniowiecznego uniwersytetu - wydział sztuk ( $\mathrm{z}$ podziałem na trivium $\mathrm{i}$ quadrivium) przedstawili Gordon Leff i John North; medyczny - Nancy Siraisi, praw - Antonio Garcia y Garcia, teologiczny - Monika Asztalos.

Tom ten kończy epilog przedstawiający początki humanizmu, zmian jakie pod jego wpływem nastapiły $w$ dziedzinie edukacji, a szczególnie jego wpływ na przemiany w szkolnictwie wyższym.

Każdy z rozdziałów uzupełnia wybrana bibliografia, całość zaś indeksy - osobowy oraz 
geograficzny i tematyczny, pozwalające na sprawniejsze posługiwanie się tekstem.

Jest to praca cenna dla badaczy nie tylko dziejów szkolnictwa i kultury okresu średniowiecza, ale dla wszystkich którzy okresem tym się zajmują. Poprzednio ukazało się wiele rozmaitych opracowań omawiających dzieje uniwersytetów od średniowiecza począwszy, najczęściej jednak nie zaspokajały one wymagań, były zbyt ogólne i niewystarczające lub na obecnym etapie po prostu przestarzałe. Omawiany tom, będący początkiem nowego opracowania całości dziejów uniwersytetów zachęca do zapoznania się $z$ częściami następnymi. Kolejny tom pod redakcja $H$. de Ridder-Symoens dotyczyć będzie dziejów uniwersytetów we wczesnym okresie nowożytnym. Jego układ będzie zbliżony do tomu pierwszego i doprowadzi nas aź do czasów Oświecenia.

\section{Wiesław Jamrożek, Idee edukacyjne polskiej socjalnej demokracji w Galicji do 1918 roku, Wyd. Eruditus, Poznań 1994, ss. 204.}

Nakładem poznańskiego wydawnictwa naukowego „Eruditus", została wydana monografia pt. „Idee edukacyjne polskiej socjalnej demokracji w Galicji do 1918 roku". Książka ta, jako opracowanie historyczno-oświatowe, znakomicie wypełnia lukę $w$ badaniach historycznych nad dziejami ruchu socjalistycznego, w tym głównie socjalnej demokracji w Galicji przed odzyskaniem przez Polskę niepodległości. Dotychczasowe bowiem badania, znajdujące swoje odzwierciedlenie w bogatej historiografii, dotyczą przede wszystkim działalności politycznej socjaldemokracji. Marginalnie natomiast rozpatrywano problematykę idei edukacyjnych galicyjskiej socjalnej demokracji i łączące się z tym zagadnienia jej udziału w wysiłkach na rzecz demokratyzacji stosunków społecznych i rozwoju oświaty w Galicji. Praca W. Jamrożka, prezentując stanowisko galicyjskiej partii wobec wszystkich wazniejszych, aktualnych na przełomie XIX i XX wieku zagadnień i zjawisk oświatowych oraz dokonując udanej próby rekonstrukcji oryginalnych koncepcji pedagogicznych wypracowanych przez działaczy tego ugrupowania, ujęła te tematyke w sposób całościowy.

Jej strukturę wyznaczają cztery zasadnicze rozdziały, w ramach których w układzie problemowo-chronologicznym, autor poddał analizie pedagogicznej wiele szczegółowych zagadnień.
W pierwszym rozdziale, kierując się dyrektywą metodologiczną wiązania myśli pedagogicznej z panującymi w danym czasie systemami i prądami filozoficznymi oraz usytuowania ich w szerokim kontekście uwarunkowań społeczno-politycznych, ekonomicznych i ideologicznych, Autor wyprowadził geneze idei i postulatów edukacyjnych galicyjskiej socjalnej demokracji. Rozdział drugi został poświęcony prezentacji stanowiska partii wobec problemów edukacji na poziomie szkoły ludowej, średniej ogólnoksztalcącej i zawodowej oraz szkolnictwa ukraińskiego w latach 1890 - 1918. W kolejnym rozdziale, omówione zostały poglądy, postulaty i koncepcje tego ugrupowania politycznego dotyczące edukacji pozaszkolnej. Szczególnie wyeksponowano rozważania teoretyczne i zalożenia organizacyjno-programowe wychowania spoleczno-politycznego, czytelnictwa, ruchu samokształceniowego, edukacji kulturalnej, oświaty zdrowotnej, sportu i turystyki. W tym kontekście autor przedstawił udział działaczy socjalnej demokracji w wypracowaniu profilu działalności Uniwersytetu Ludowego im. A. Mickiewicza i Uniwersytetu Wakacyjnego w Zakopanem. W rozdziale ostatnim zaprezentowano bardzo interesujące ustalenia na temat wychowawczego funkcjonowania rodziny i postulatów dotyczących edukacji pedagogicznej rodziców oraz organizacji opieki nad dziécmi w środowisku robotniczym.

Krzysztof Jakubiak 